Bolm Inst. oceanogr., S Paulo, 31(2):9-11, 1982

\title{
ON AN INTERESTING SPECIMEN OF COWNOSE RAY (PISCES: RHINOPTERIDAE) FROM THE COLOMBIAN CARIBBEAN
}

\author{
Arturo ACERO P. ${ }^{1,2}$ \& Jaime GARZON F. ${ }^{1}$ \\ 1 Instituto de Investigaciones Marinas de Punta de Betín (INVEMAR)* \\ 2 Rosenstiel School. of Marine and Atmospheric Science, University of Miami
}

\section{Synopsis}

The collection of a specimen of cownose ray in the Colombian Caribbean is reported. Based on the presence of 9 rows of teeth in both jows, it was identified as

Rhinoptera brasiliensis Müller \& Henle. The range of the species is extended 7,300 $\mathrm{km}$, from Rio de Janeiro to Isla de Salamanca. Some comments on the size at birth and habits of the species are made.

\section{Introduction}

The family of batoid fishes Rhinopteridae includes only the genus Rhinoptera with approximately 10 species occurring worldwide in tropical and warm temperate coastal waters (Bigelow \& Schroeder, 1953). Two general works about the southern Caribbean fishes have been published in recent years (Cervigón, 1966; Dah1, 1971), but they do not report the presence of cownose rays in the areas studied.

On September 22, 1981, fishermen using a beach seine collected a male specimen of Rhinoptera (Fig. 1) on the seaward side of Isla de Salamanca $\left(71^{\circ} 18^{\prime} \mathrm{W}\right.$; $\left.11^{\circ} 00^{\prime} \mathrm{N}\right)$, Colombian Caribbean. The specimen is deposited in the fish collection of the Instituto de Investigaciones Marinas de Punta de Betín (INVEMAR-P 0615). The morphometric data were taken following the methods of Bigelow \& Schroeder (1953).

\section{Material}

The specimen has 9 rows of teeth in both upper and lower jaws, only one caudal spine, and an umbilical scar. Its morphometric data (mm) are: disc breadth 333; disc length 189; snouth length in front of orbits 4; snout length in front of mouth 30; horizontal diameter of orbit 8 ; distance between orbits 60 ; distance between spiracles 55 ; mouth breadth 39 ; distance between inner ends of nostrils 28; 1st gill opening length 9; 3rd gill opening length 9.5 ; 5 th gill opening length 6 ; distance between inner ends of

* INVEMAR - Apartado Aéreo 1016, Santa Marta, Colombia.

Publ. no 535 do Inst. oceanogr. da Usp. 1st gill openings 54 ; distance between inner ends of 3rd gill openings 46; distance between inner ends of 5 th gill openings 38 ; vertical height of dorsal fin 13; lenght of base of dorsal fin 19;



Fig. 1. Dorsal (upper) and ventral (lower) views of a young male specimen of Rhinoptera brasiliensis (INVEMAR - P 0615; $333 \mathrm{~mm}$ di sc breadth) collected in the Colombian Caribbean. 
Bolm Inst. oceanogr., S Paulo, 31(2), 1982

outer margin of pelvic fins 30; lenght of inner margins of claspers 5.6; distance from tip of snout to center of cloaca 175; distance from center of cloaca to tip of tail 352. The teeth of the median series of the upper jaw are 4.9 times as broad (transversely) as long (anteroposteriorly), those of the first series outward are 3.8 times as broad as long, and those of the next series are 1.8 times as broad as long. The coloration of the fresh specimen was greenish gray dorsally, whitish ventrally and blackish on the tail posterior to the spine.

\section{Discussion}

Bigelow \& Schroeder (1953) distinguished two western Atlantic species of cownose rays, R. brasiliensis Müller and Henle, 1841, and R. bonasus

(Mitchi11), 1815, separating them by the number of tooth rows in each jaw, 7 in $R$. bonasus and 9 in $R$. brasiliensis. They discussed the advantage of retaining single species status for these two forms since they are apparently identical in other aspects and there are specimens with intermediate counts. They considered it wise, however, to keep them as distinct species. Schwartz (1965) regarded all the western Atlantic Rhinoptera as belonging to one species which should be called $R$. bonasus. Unfortunately he did not give evidence for this in the published abstract of his work. Figueiredo (1977) followed Schwartz and reported one species from southeast Brazil, without commenting on the problem, while Roux (1979) recorded both taxa from that country, again without comments. J. D. McEachran and M. Stehmann (pers. comm., 1981) favor Bigelow \& Schroeder's decision to consider them as valid species. The distributional range of $R$. bonasus includes the Atlantic and Gulf of México coasts of the United States and the coasts of México, Cuba, Venezuela, Trinidad, Guyana and Brazil (Bigelow \& Schroeder, 1953; Schwartz, 1965); R. brasiliensis was known only from Brazil (Bigelow \& Schroeder, 1953).

As we do not have enough material to discuss the systematic status of the western Atlantic Rhinoptera, we follow the opinion of McEachran and Stehmann and consider our specimen the first report of a Caribbean cownose ray with 9 teeth rows in each jaw, i. e. the first Caribbean record of $R$. brasiliensis. This represents, therefore, a range extension for the species of $7,300 \mathrm{~km}$ towards the northwest, from Rio de Janeiro to Isla de Salamanca. Bigelow \& Schroeder (1953) supposed that the species is born with a breadth of about $450-500 \mathrm{~mm}$, while our specimen is only $333 \mathrm{~mm}$ wide, and, hence, the smallest free living juvenile of $R$. brasiliensis collected. The Colombian specimen is also smaller than any reported free living juvenile of $R$. bonasus, since those authors referred to a 13.5 in (approximately $343 \mathrm{~mm}$ ) embryo of this species. Nothing was known of the habits of $R$. brasiliensis (Bigelow \& Schroeder, 1953). Our specimen was caught in less than $3 \mathrm{~m}$ of water over a sandy bottom, near the mouth of the largest estuarine lagoon of the Colombiam Caribbean, along with fishes of the families Sciaenidae, Clupeidae, Engraulidae, Trichiuridae, Gerreidae and Centropomidae. The stomach contained organic matter and fragments of gastropod and opisthobranch she11s.

Schwartz (1965) discussed the migrations of the western Atlantic cownose rays and indicated that one stock of $R$. bonasus (the only species he accepted) arrives at the northern coast of South America in mid-January from the Atlantic coast of the United States, while a second stock is restricted to the Gulf of México. Our specimen is very young, since it still has an umbilical scar, and it was collected in September when the migratory stock of northern $R$. bonasus is between Chesapeake Bay and Cape Hatteras (Schwartz, 1965). The capture of this specimen in Colombia is inconsistent with the conclusions of Schwartz (1965) regarding the systematics and population structure of western Atlantic Rhinoptera.

\section{Acknowledgments}

The specimen was brought to our attention by 0. Galvis, J. Gallo, L. Pérez, D. Zamorano and S. Zea. Drs. J. D. McEachran (Texas A\&M University, College Station, TX, U.S.A), N. A. Menezes (Museu de Zoologia, Universidade de São Paulo, São Paulo, Brasil) and M. Stehmann (Institut für Seefischerei, Hamburg, West Germany) kindly commented on the case. D. J. Gordon corrected the English text. 
COLCIENCIAS sponsors the ichthyological work of the authors. Contribution No 242, INVEMAR.

\section{Resumen}

Se registra la colecta de un especimen de raya de la familia Rhinopteridae en el Caribe colombiano, el cual tiene 9 filas de dientes en ambas mandíbulas. Este carācter 1o incluye en la especie Rhinoptera brasiliensis Müller \& Henle, extendiendo su rango $7.300 \mathrm{~km}$, de Rio de Janeiro hasta la Isla de Salamanca. Se hacen comentarios sobre la talla de nacimiento y los hābitos de la especie.

\section{References}

BIGELOW, H. B. \& SCHROEDER, W. C. 1953. Sawfishes, guitarfishes, skates and rays. In: Fishes of the western North Atlantic. Mem. Sears Fdn Mar. Res., 1 (2): 1-154.

CERVIGON M., F. 1966. Los peces marinos de Venezuela. Caracas, Fundación La Salle de Ciencias Naturales, Monografías 11 y 12, 951 p.
DAHL, G. 1971. Los peces del norte de Colombia. Bogotá, INDERENA, 391 p.

FIGUEIREDO, J. L. de 1977. Manual de peixes marinhos do Sudeste do Brasil. I. Introdução. Cações, raias e quimeras. São Paulo, Museu de Zoologia da Universidade de São Paulo, 104 p.

ROUX, C. 1979. Poisson chondrichthyens du plateau continental brésilien et du Río de la Plata. Campagne de la Calypso au large des côtes atlantiques de 1'Amerique du Sud (1960-1961). Première partie. Annls Inst. oceanogr., Monaco, 55(11):111-130.

SCHWARTZ, F. J. 1965. Inter-American migrations and systematics of the western Atlantic cownose ray, Rhinoptera bonasus (abstract): 1 . In: Association of Island Marine Laboratories of the Caribbean, Sixth Meeting, Isla de Margarita, Venezuela, $18 \mathrm{p}$.

(Manuscript received on $01 / \mathrm{Dec} / 1981$; accepted on 14/Sep./1982)

\section{Addendum}

When this paper was in press the authors examined 3 more specimens of Rhinoptera brasiliensis which were collected on May 4 and September 22, 1982 in the same 1ocality and conditions as the first individual. These specimens, which are also juveniles (disc breadth $305-445 \mathrm{~mm}$ ), have 9 rows of teeth in both upper and lower jaws. The capture of these fishes confirms the inconsistence of Schwartz (1965) conclusions about the status of the cownose rays in the western Atlantic. 